\title{
LII. Relations between the physical properties of liquids at the boiling-point
}

\section{Tyrer}

To cite this article: D. Tyrer (1910) LII. Relations between the physical properties of liquids at the boiling-point, Philosophical Magazine Series 6, 20:117, 522-533, DOI: $10.1080 / 14786441008636930$

To link to this article: http://dx.doi.org/10.1080/14786441008636930

曲 Published online: 21 Apr 2009.

Submit your article to this journal $₫$

Џll Article views: 3

Q View related articles $\square$

4 Citing articles: 1 View citing articles ๘ 
The thermal conductivity was measured by the slab method -a slab of about $300 \mathrm{sq} . \mathrm{cm}$. area and of a thickness of $-245 \mathrm{~cm}$. being pressed between a steam and a cold-water vessel. The temperatures of the cold water were read from minute to minute as they rose. Careful corrections were made for " radiation" loss from the cold vessel. Two distinct sets of readings were taken. The values of the conductivity obtained were $\cdot 000150$ and $\cdot 000141$ respectively. Taking the mean of these and employing the value obtained experimentally for the emissivity, viz. ${ }^{\circ} 000275$, the critical radius becomes $.527 \mathrm{~cm}$. The value read off from fig. 3 is about -57. The agreement is as good as was to be expected.

The conclusions to be drawn from these experiments are that:

(1) On narrow steam-pipes, up to about half a cm. external radius, the application of an asbestos coating encourages the escape of heat. This radius is below what may be termed engineering dimensions. But in experimental apparatus it is not at all an unusually small radius; and for such pipes the application of lagging is a delicate question.

(2) When the radius is much smaller than this critical value, the coat must have an external radius much greater than half a centimetre before the lagging efficiency is as good as without a coat at all. Thus, the curve would seem to show that the escape of heat is the same for external radii of $\cdot 24 \mathrm{~cm}$. and $2 \cdot 0 \mathrm{cms}$.

LII. Relations between the Physical Properties of Liquids at the Boiling-Point. By D. TYRER *.

A SIMPLE relation exists between the latent heat of A vaporization of a liquid and the molecular volume at the boiling-point. The relation may be expressed

$$
\mathrm{LM}=\mathrm{K} \sqrt[3]{\mathrm{V}}
$$

where $\mathrm{L}$ is the latent heat of a liquid at its boiling-point, $\mathrm{V}$ the molecular volume at the boiling-point, $\mathrm{M}$ the molecular weight, and $\mathrm{K}$ a constant. This relation, which may for the present be regarded as empirical, holds with a fair degree of accuracy for most classes of substances. In the Table given below the values of the molecular volumes are the mean values of the results chiefly of Kopp, Pierre, Schiff, Thorpe, Gartenmeister, and Young. In the last column are given the latent heats calculated according to the above equation, the value of $\mathrm{K}$ having been taken as 1583 . This figure is the mean value of $K$ for the aliphatic esters, calculated from the results of Schiff and J. C. Brown. As Brown's

* Communicated by Prof. H. B. Dixon, F.R.S. 
results are invariably higher than those of Schiff, the agreement between the calculated and observed values of the latent heat will not be so good in those cases where the results of only one of the above observers are known.

\begin{tabular}{|c|c|c|c|c|c|}
\hline Liquid. & $\begin{array}{c}\text { Molecular } \\
\text { Volume V } \\
\text { at the } \\
\text { Boiling- } \\
\text { Point. }\end{array}$ & $\begin{array}{c}\text { Latent } \\
\text { Heat } \\
\text { (observed). }\end{array}$ & Authority. & Mean. & $\begin{array}{c}\text { Latent } \\
\text { Heat } \\
\text { (calculated). }\end{array}$ \\
\hline Propyl formate............ & $107 \cdot 0$ & $\left\{\begin{array}{l}85 \cdot 25 \\
90 \cdot 36\end{array}\right.$ & $\begin{array}{l}\text { Schiff } \\
\text { Brown }\end{array}$ & $87 \cdot 80$ & $85 \cdot 41$ \\
\hline Isobutyl formate .... & $129 \cdot 9$ & $\left\{\begin{array}{l}77 \cdot 0 \\
80 \cdot 12\end{array}\right.$ & $\begin{array}{l}\text { Sohiff } \\
\text { Brown }\end{array}$ & $78: 56$ & 78.52 \\
\hline Isoamyl formate & 151 & $\left\{\begin{array}{l}71 \cdot 65 \\
73 \cdot 75 \\
98 \cdot 26\end{array}\right.$ & $\begin{array}{l}\text { Schiff } \\
\text { Brown } \\
\text { Brown }\end{array}$ & $72 \cdot 70$ & $72 \cdot 60$ \\
\hline Methyl acetate.. & $83 \cdot 7$ & $97 \cdot 0$ & $\begin{array}{l}\text { Brown } \\
\text { Ramsay \& } \\
\text { Marshall }\end{array}$ & $97 \cdot 63$ & $93: 57$ \\
\hline Ethyl acetate. & $106 \cdot 0$ & $\begin{array}{l}83 \cdot 1 \\
88 \cdot 37\end{array}$ & $\begin{array}{l}\text { Schiff } \\
\text { Brown }\end{array}$ & $85 \cdot 73$ & $85 \cdot 13$ \\
\hline Propyl acetate ......... & $128 \cdot 4$ & $\left\{\begin{array}{l}77 \cdot 3 \\
80 \cdot 45\end{array}\right.$ & $\begin{array}{l}\text { Schiff } \\
\text { Brown }\end{array}$ & $78 \cdot 87$ & $78 \cdot 24$ \\
\hline Butyl acetate............ & $150 \cdot 6$ & $73 \cdot 9$ & Brown & $73 \cdot 9$ & $72 \cdot 65$ \\
\hline Isobutyl acetate ..... & $150 \cdot 1$ & $\left\{\begin{array}{l}69 \cdot 9 \\
72 \cdot 46\end{array}\right.$ & $\begin{array}{l}\text { Schiff } \\
\text { Brown }\end{array}$ & $71 \cdot 18$ & $72 \cdot 47$ \\
\hline Isoamyl acetate.. & 174 & $\begin{array}{l}66 \cdot 35 \\
69 \cdot 00\end{array}$ & $\begin{array}{l}\text { Schiff } \\
\text { Brown }\end{array}$ & $67 \cdot 67$ & $67 \cdot 94$ \\
\hline Methyl propionate ... & $104 \cdot 6$ & $\begin{array}{l}84 \cdot 15 \\
89 \cdot 0\end{array}$ & $\begin{array}{l}\text { Schiff } \\
\text { Brown }\end{array}$ & 86.57 & $84 \cdot 7 \cdot 2$ \\
\hline Propyl propionate & $150 \cdot 0$ & $\left\{\begin{array}{l}71 \cdot 5 \\
73 \cdot 73\end{array}\right.$ & $\begin{array}{l}\text { Schiff } \\
\text { Brown }\end{array}$ & $72 \cdot 61$ & $72 \cdot 46$ \\
\hline Ethyl propionate ....... & $127 \cdot 8$ & $\left\{\begin{array}{l}77 \cdot 1 \\
80 \cdot 3\end{array}\right.$ & $\begin{array}{l}\text { Sehiff } \\
\text { Brown }\end{array}$ & $78 \cdot 7$ & $78 \cdot 72$ \\
\hline Isobutyl propionate.... & 174 & 66.0 & Sohiff & $66 \cdot 0$ & $67 \cdot 14$ \\
\hline Isoamyl propionate ... & 196 & $\left\{\begin{array}{l}63.05 \\
65.31\end{array}\right.$ & $\begin{array}{l}\text { Schiff } \\
\text { Brown }\end{array}$ & $6+18$ & $63 \cdot 8$ \\
\hline Methyl butyrate & $126 \cdot 7$ & $\left\{\begin{array}{l}77 \cdot 25 \\
79 \cdot 75\end{array}\right.$ & $\begin{array}{l}\text { Schiff } \\
\text { Brown }\end{array}$ & $78 \cdot 50$ & $78 \cdot 07$ \\
\hline Ethyl butyrate ... & $150 \cdot 4$ & $71 \cdot 5$ & $\begin{array}{l}\text { Schiff } \\
\text { Brown }\end{array}$ & 7257 & $72 \cdot 52$ \\
\hline Propyl butyrate ....... & $173 \cdot 9$ & $\left\{\begin{array}{l}66 \cdot 2 \\
68 \cdot 29\end{array}\right.$ & $\begin{array}{l}\text { Schiff } \\
\text { Brown }\end{array}$ & $67 \cdot 24$ & $67 \cdot 98$ \\
\hline Propyl isovalerate ...... & $192 \cdot 2$ & $64 \cdot 37$ & Brown & $64: 37$ & 6891 \\
\hline Isoamyl butyrate ...... & $221 \cdot 5$ & $\left\{\begin{array}{l}59 \cdot 4 \\
61 \cdot 59\end{array}\right.$ & $\begin{array}{l}\text { Schiff } \\
\text { Brown }\end{array}$ & $60 \cdot 50$ & $60 \cdot 58$ \\
\hline Isobutyl butyrate .. & $199 \cdot 2$ & $\left\{\begin{array}{l}61 \cdot 9 \\
64 \cdot 59\end{array}\right.$ & $\begin{array}{l}\text { Sehiff } \\
\text { Brown }\end{array}$ & $63 \cdot 24$ & $64 \cdot 16$ \\
\hline Methyl isobutyrate & $126 \cdot 5$ & $\left\{\begin{array}{l}75 \cdot 5 \\
79 \cdot 07\end{array}\right.$ & $\begin{array}{l}\text { Schiff } \\
\text { Brown }\end{array}$ & $77 \cdot 28$ & $77 \cdot 9$ \\
\hline Ethyl isobutyrate............... & $150 \cdot 7$ & $\begin{array}{l}69 \cdot 2 \\
71 \cdot 75\end{array}$ & $\begin{array}{l}\text { Schiff } \\
\text { Brown }\end{array}$ & $70 \cdot 47$ & 7256 \\
\hline Propyl isobutyrate ............ & 174 & 6.9 & Schiff & 63.9 & $67 \cdot 94$ \\
\hline Isobutyl isobutyrate............. & $199 \cdot 2$ & $\left\{\begin{array}{l}59 \cdot 95 \\
63 \cdot 4\end{array}\right.$ & $\begin{array}{l}\text { Sehiff } \\
\text { Brown }\end{array}$ & 61.67 & $64 \cdot 16$ \\
\hline 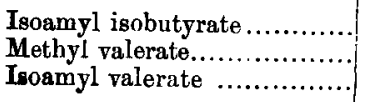 & $\begin{array}{l}223 \cdot 0 \\
149 \cdot 1 \\
245 \cdot 5\end{array}$ & $\begin{array}{l}57 \cdot 65 \\
69 \cdot 95 \\
56 \cdot 2\end{array}$ & $\begin{array}{l}\text { Schiff } \\
\text { Scliff } \\
\text { Schiff }\end{array}$ & $\begin{array}{l}57 \cdot 65 \\
69 \cdot 95 \\
56 \cdot 2\end{array}$ & $\begin{array}{l}60 \cdot 72 \\
72 \cdot 31 \\
57 \cdot 25\end{array}$ \\
\hline
\end{tabular}


524 Mr. D. Tyrer on Relations between the Physical

\begin{tabular}{|c|c|c|c|c|c|}
\hline Liquid. & $\begin{array}{l}\text { Moleoular } \\
\text { Volume V } \\
\text { at the } \\
\text { Boiling- } \\
\text { Point. }\end{array}$ & $\begin{array}{c}\text { Latent } \\
\text { Heat } \\
\text { (observed), }\end{array}$ & Authority. & Mean. & $\begin{array}{c}\text { Latent } \\
\text { Heat } \\
\text { (calculated) }\end{array}$ \\
\hline 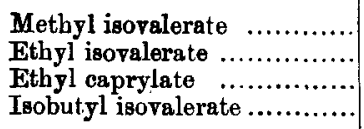 & $\begin{array}{l}148 \cdot 7 \\
173 \cdot 3 \\
1977 \\
222\end{array}$ & $\begin{array}{l}72 \cdot 38 \\
67 \cdot 84 \\
60 \cdot 46 \\
60 \cdot 41\end{array}$ & $\begin{array}{l}\text { Brown } \\
\text { Brown } \\
\text { Brown } \\
\text { Brown }\end{array}$ & $\begin{array}{l}72 \cdot 38 \\
67 \cdot 84 \\
60 \cdot 46 \\
60 \cdot 41\end{array}$ & $\begin{array}{l}72 \cdot 25 \\
67 \cdot 85 \\
63 \cdot 99 \\
60 \cdot 63\end{array}$ \\
\hline Etbyl nonylate .................. & $\left\{\begin{array}{l}270(\text { cal- } \\
\text { culated) }\end{array}\right.$ & $58 \cdot 08$ & Brown & $58 \cdot 08$ & $56 \cdot 0$ \\
\hline 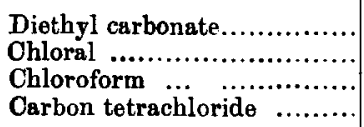 & $\begin{array}{l}138 \cdot 8 \\
108 \cdot 9 \\
84 \cdot 5 \\
103 \cdot 7\end{array}$ & $\begin{array}{l}72 \cdot 85 \\
54 \cdot 1 \\
58 \cdot 49 \\
46 \cdot 35\end{array}$ & $\begin{array}{l}\text { Louginine } \\
\text { Berthelot } \\
\text { Wirtz } \\
\text { Wirtz }\end{array}$ & $\begin{array}{l}72 \cdot 85 \\
54 \cdot 1 \\
58 \cdot 49 \\
46 \cdot 35\end{array}$ & $\begin{array}{l}68 \cdot 85 \\
51 \cdot 10 \\
58 \cdot 09 \\
52 \cdot 34\end{array}$ \\
\hline Ethyl iodide ........................ & $86 \cdot 1$ & $\left\{\begin{array}{l}46 \cdot 87 \\
46 \cdot 0\end{array}\right.$ & $\begin{array}{c}\text { Andrews } \\
\text { Kablenberg }\end{array}$ & 46.43 & $44 \cdot 54$ \\
\hline Methylene chloride .............. & $65 \cdot 12$ & $75 \cdot 3$ & $\left\{\begin{array}{c}\text { Berthelot \& } \\
\text { Ogier }\end{array}\right.$ & $75 \cdot 3$ & $74 \cdot 87$ \\
\hline Ethyl bromide ..... & $77 \cdot 7$ & $\left\{\begin{array}{l}60 \cdot 37 \\
61 \cdot 65\end{array}\right.$ & $\begin{array}{c}\text { Wirtz } \\
\text { Berthelot }\end{array}$ & $61 \cdot 01$ & $61 \cdot 98$ \\
\hline 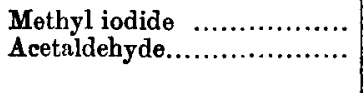 & $\begin{array}{l}63 \cdot 9 \\
56 \cdot 9\end{array}$ & $\begin{array}{c}46 \cdot 1 \\
136 \cdot 4 \\
\end{array}$ & $\begin{array}{l}\text { Andrews } \\
\text { Berthelot } \\
\text { Griffths \& }\end{array}$ & $\begin{array}{r}46 \cdot 1 \\
136 \cdot 4\end{array}$ & $\begin{array}{l}44 \cdot 54 \\
138 \cdot 3\end{array}$ \\
\hline Benzene... & $95 \cdot 9$ & $\left\{\begin{array}{l}94 \cdot 37 \\
94 \cdot 93 \\
92 \cdot 91\end{array}\right.$ & $\begin{array}{l}\text { Marsball } \\
\text { Brown } \\
\text { Wirtz }\end{array}$ & $94 \cdot 07$ & $92 \cdot 85$ \\
\hline Ethyl benzene ... ............... & $138 \cdot 8$ & $76 \cdot 4$ & Schiff & $76 \cdot 4$ & $77 \cdot 27$ \\
\hline 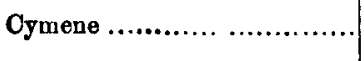 & $184 \cdot 4$ & $\left\{\begin{array}{l}66: 3 \\
67 \cdot 64\end{array}\right.$ & $\begin{array}{l}\text { Schiff } \\
\text { Brown }\end{array}$ & $67 \cdot 0$ & $67 \cdot 20$ \\
\hline Mesitylene........... & $162 \cdot 4$ & $\left\{\begin{array}{l}71 \cdot 75 \\
74 \cdot 42\end{array}\right.$ & $\begin{array}{l}\text { Schiff } \\
\text { Brown }\end{array}$ & 73.08 & 71.92 \\
\hline Propyl benzene .................. & $161 \cdot 8$ & $71 \cdot 75$ & Schiff & $71 \cdot 75$ & 71.83 \\
\hline Terp & $182 \cdot 8$ & $\left\{\begin{array}{l}68 \cdot 73 \\
68 \cdot 5 \\
83 \cdot 55\end{array}\right.$ & $\begin{array}{l}\text { Farre \& } \\
\text { Silbermann } \\
\text { Scball } \\
\text { Schiff }\end{array}$ & $68 \cdot 61$ & $66 \cdot 01$ \\
\hline Toluene.... & 117.9 & $86 \cdot 8$ & $\begin{array}{l}\text { Ramsay \& } \\
\text { Marshall }\end{array}$ & 85.92 & $84 \cdot 34$ \\
\hline o-Xylene .... & $138 \cdot 7$ & $\begin{array}{l}8 \cdot 43 \\
82 \cdot 47\end{array}$ & $\begin{array}{l}\text { Brown } \\
\text { Brown }\end{array}$ & $82 \cdot 47$ & $77 \cdot 25$ \\
\hline m-Xylene $\ldots \ldots \ldots \ldots \ldots \ldots \ldots \ldots$ & $139 \cdot 7$ & $\left\{\begin{array}{l}81 \cdot 34 \\
78 \cdot 25\end{array}\right.$ & $\begin{array}{l}\text { Brown } \\
\text { Sehiff }\end{array}$ & $79 \cdot 77$ & $77 \cdot 44$ \\
\hline 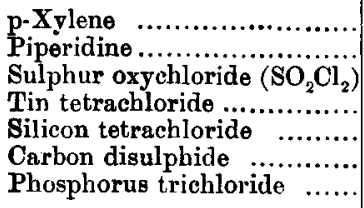 & $\begin{array}{r}140 \cdot 2 \\
106 \cdot 3 \\
86 \cdot 3 \\
131 \cdot 2 \\
123 \cdot 4 \\
62 \cdot 1 \\
93 \cdot 4\end{array}$ & $\begin{array}{l}80 \cdot 98 \\
88 \cdot 9 \\
52 \cdot 4 \\
30 \cdot 33 \\
37 \cdot 3 \\
83 \cdot 81 \\
51 \cdot 4\end{array}$ & $\begin{array}{l}\text { Brown } \\
\text { Louginine } \\
\text { Ogier } \\
\text { Andrews } \\
\text { Ogier } \\
\text { Wirtz } \\
\text { Andrews }\end{array}$ & $\begin{array}{l}80 \cdot 98 \\
88 \cdot 9 \\
52 \cdot 4 \\
30 \cdot 33 \\
37 \cdot 3 \\
83 \cdot 81 \\
51 \cdot 4\end{array}$ & $\begin{array}{l}77 \cdot 53 \\
88 \cdot 8 \\
51 \cdot 79 \\
30 \cdot 91 \\
46 \cdot 3 \\
82 \cdot 43 \\
52 \cdot 4\end{array}$ \\
\hline 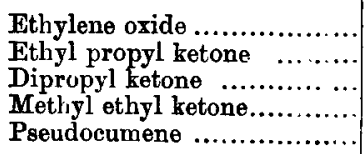 & $\begin{array}{l}51 \cdot 8^{*} \\
143 \cdot 3^{*} \\
165 \cdot 3^{*} \\
99 \cdot 3^{*} \\
176^{*}\end{array}$ & $\begin{array}{c}138 \cdot 6 \\
82 \cdot 96 \\
75 \cdot 94 \\
103 \cdot 4 \\
72 \cdot 8\end{array}$ & $\begin{array}{l}\text { Berthelot } \\
\text { Louginine } \\
\text { Louginine } \\
\text { Louginine } \\
\text { Schiff }\end{array}$ & $\begin{array}{c}138 \cdot 6 \\
82 \cdot 96 \\
75 \cdot 94 \\
103 \cdot 4 \\
72 \cdot 8\end{array}$ & $\begin{array}{c}134 \cdot 1 \\
82 \cdot 78 \\
76 \cdot 17 \\
101 \cdot 7 \\
72 \cdot 67\end{array}$ \\
\hline
\end{tabular}

* These values of $V$ are calculated from the atomic volumes of Kopp, experimental ralues not being obtaimble. 
Properties of Liquids at the Boiling-Point.

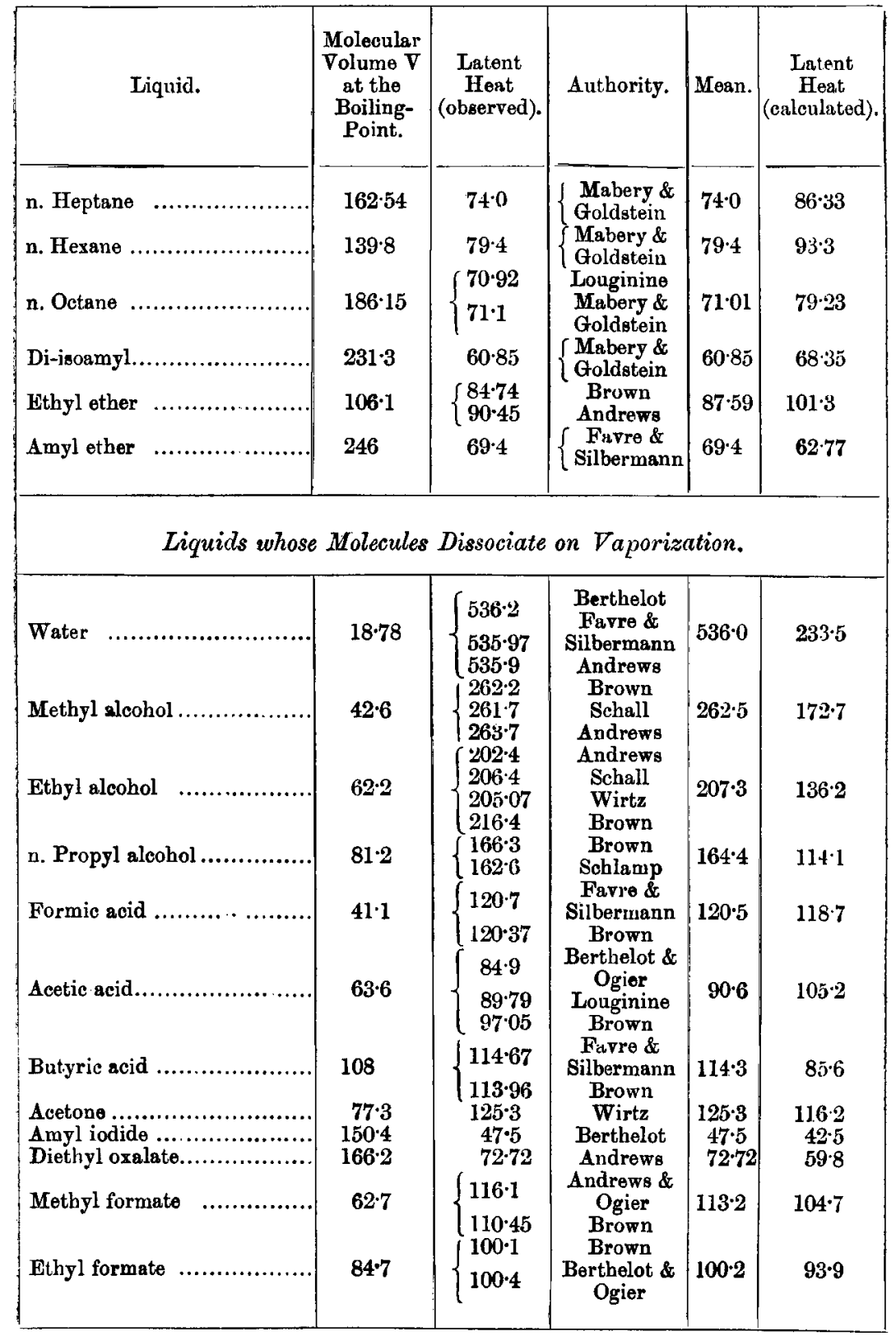


It will be observed from the Table that there is a close agreement between the calculated and observed values of the latent heat. The only classes of substances which do not seem to conform to the relationship are the aliphatic hydrocarbons and ethers and of course associated liquids as the hydroxyl compounds. The validity of the relation is in general affected by the following factors :-

(1) Experimental errors in the values of the latent heats. These are rather considerable as a comparison of the results of different observers shows. The difference between the calculated and observed values of the latent heat does, as a general rule, come easily within the range of experimental errors except in the fews cases mentioned above.

(2) Association of the molecules and their dissociation on raporization.

The Effect of Molecular Association on the Relation.

The last portion of the above Table deals with liquids which show molecular association, and it will be observed that in these cases there are very wide divergences between the calculated and observed values of the latent heats. The question may be divided into two cases, viz. :-

(a) Liquids whose molecules are associated but which do not dissociate on vaporization.

(b) Liquids whose molecules dissociate on vaporization.

Case (a).-In the first case the relation should obviously be written

$$
\mathrm{LM} n=\mathrm{K} \sqrt[3]{\overline{\nabla n}}
$$

where $n$ is the association factor.

The true latent heat then becomes

$$
\mathrm{L}=\frac{\mathrm{K} \sqrt[3]{ } \mathrm{V}}{\mathrm{M} n^{\frac{3}{3}}}
$$

Whereas the latent heat $\mathrm{L}_{1}$ calculated according to the equation without considering association is

$$
\mathrm{L}_{1}=\frac{\mathrm{K}{ }^{3} \vee \overline{\mathrm{V}}}{\mathrm{M}}
$$

For this class of liquids, therefore, the calculated values of the latent heats will be greater than the observed values.

Case (b).-The second case includes liquids like water, whose molecules are associated in the liquid state, but are normal in the vapour state, and also liquids like amyl iodide, 
which on vaporization suffers a partial chemical dissociation into amylene and hydriodic acid.

Suppose that the process of vaporization takes place in two stages, viz.:-(1) The vaporization of the associated molecules without dissociation ; (2) the dissociation of the associated molecules of vapour. Let the heat absorbed per associated molecule in the first stage be $\mathrm{HM} n$, where $\mathrm{H}$ is the specific heat absorbed, $M$ is the molecular weight, and $n$ is the association factor. This will be equal to $\mathrm{K} \sqrt[3]{\mathrm{V} n}$. For the second stage let the heat absorbed per associated molecule be $\mathrm{XM} n$, where $\mathrm{X}$ is the specific heat absorbed. Therefore in the complete vaporization of one associated molecule the total heat absorbed (apart from heat required to do external work) may be written

$$
\mathrm{HM} n+\mathrm{XM} n=\mathrm{K} \sqrt[3]{\overline{\mathrm{V}}}+\mathrm{XM} n \text {. }
$$

And if $\lambda$ represents the heat required to do external work during the second stage of the vaporization, the true latent, heat $L_{1}$ of vaporization becomes

$$
\begin{aligned}
\mathrm{L}_{1} & =\frac{1}{\mathrm{M} n}\{\mathrm{~K} \sqrt[3]{\mathrm{V} n}+\mathrm{XM} n\}-\lambda, \\
& =\frac{\mathrm{K} \sqrt[3]{\mathrm{V}}}{\mathrm{M}^{\frac{2}{3}}}+\mathrm{X}-\lambda .
\end{aligned}
$$

Whereas the calculated latent heat not considering molecular association is

$$
\mathrm{L}=\frac{\mathrm{K} \sqrt[3]{\mathrm{V}}}{\mathrm{M}}
$$

Therefore we may say that for liquids where molecular dissociation occurs on vaporization, the latent heat calculated according to the equation $\mathrm{LM}=1583 \sqrt[3]{\bar{V}}$ may be either greater or smaller than the observed latent heat according to the magnitude of the heat of dissociation.

It may therefore happen that an associated liquid might not show any deviation from the equation $L M=K^{3} \sqrt{V}$. An example is formic acid for which, as it will be noticed from the Table, the calculated value of the latent heat is very close to the observed result. Water and the alcohols give calculated values lower than the observed, whilst some of the acids give higher and some lower calculated values.

On the whole it may be said that with the exception of the aliphatic hydrocarbons and ethers, the relation holds for normal liquids with an exactitude which quite corresponds to the exactitude of the latent heat determinations. 


\section{Mr. D. Tyrer on Relations between the Physical}

Indeed, by the aid of the equation $L M=K \sqrt[3]{V}$, the latent heat of a liquid (other than those excepted above) can be calculated merely from a knowledge of its formula with a very fair degree of accuracy. In the above table the values of the molecular volume for several liquids marked with an asterisk are calculated from Kopp's atomic volumes, and it will be noticed that in these cases there is a very fair agreement between the calculated and observed latent heats.

\section{A Relation between the Molecular Volume and the Boiling-Point.}

If the relation $\mathrm{LM}=\mathrm{K} \sqrt[3]{\mathrm{V}}$ be combined with Trouton's equation $\mathrm{LM}=20.5 \mathrm{~T}$ we get a very simple equation

$$
\mathrm{T}=\mathrm{K}_{1} \sqrt[3]{\mathrm{V}}
$$

where $T$ is the temperature of boiling, $V$ is the molecular volume at the boiling-point, and $K_{1}$ is a constant.

The value of the constant in Trouton's equation varies for normal liquids from about 19.5 to 22.5 . Taking the constant in the equation $\mathrm{LM}=\mathrm{K} \sqrt[3]{\mathrm{V}}$ as equal to 1583 we should expect that the value of $K_{1}$ will vary roughly between 70 and 80 , and will have a very small value for the aliphatic hydrocarbons and ethers.

The validity of the equation is tested in the following Table. The values of $T$ and $V$ are the mean results of Kopp, Pierre, Buff, Thorpe, Zander, Gartenmeister, Young, and others.

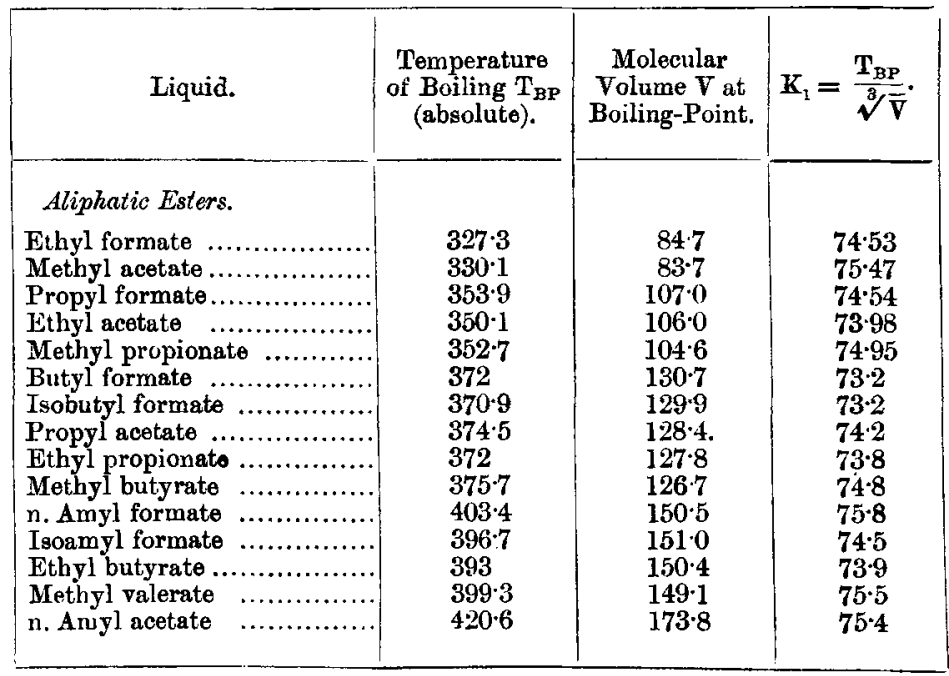




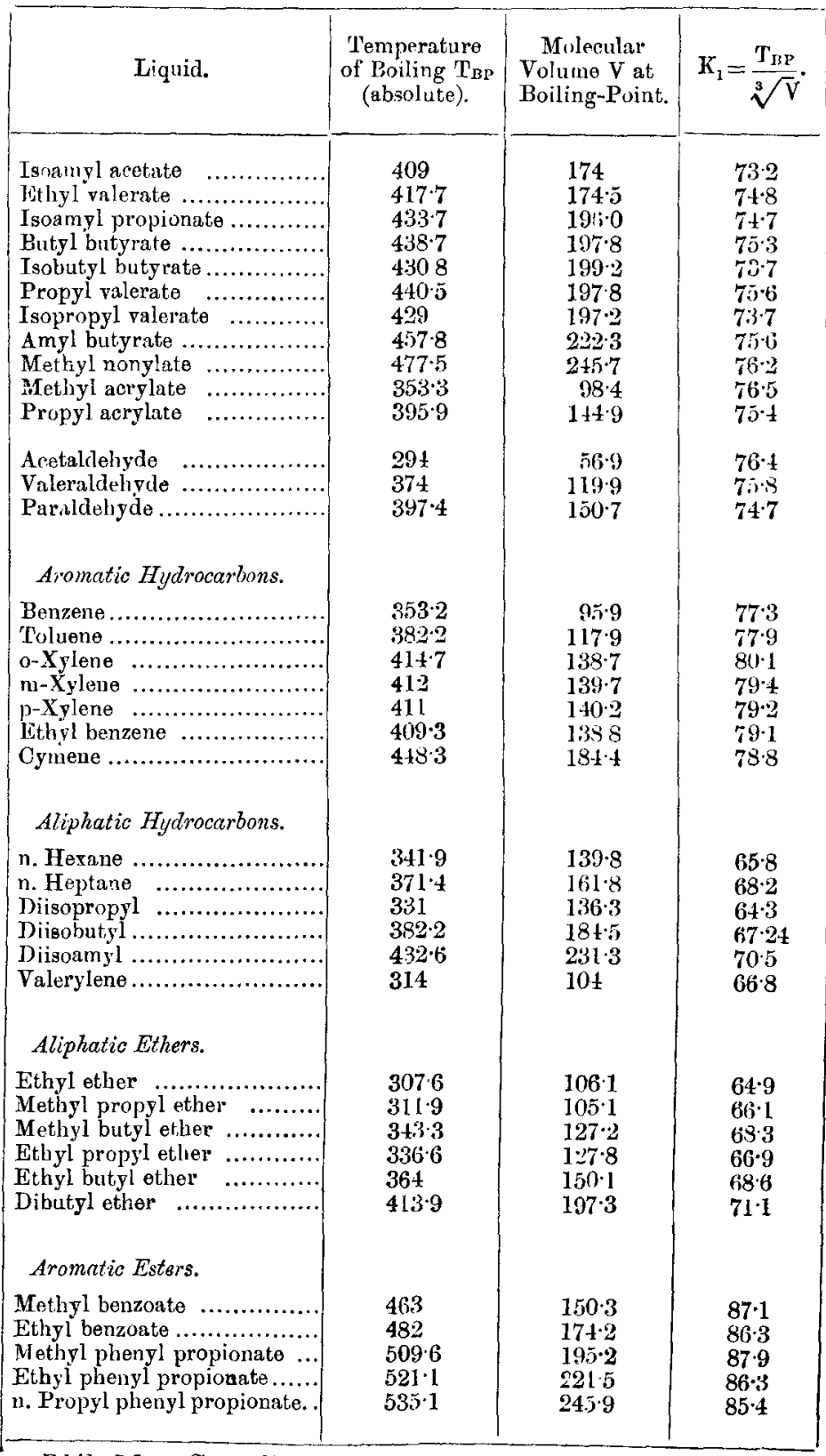

Phil. Mag. S. 6. Vol. 20. No. 117. Sept. 1910. 2 N 


\begin{tabular}{|c|c|c|c|}
\hline Liquid. & $\begin{array}{l}\text { Tempezature } \\
\text { of Boiling T Ty } \\
\text { (absulute). }\end{array}$ & $\begin{array}{l}\text { Molecular } \\
\text { Volume V at } \\
\text { Boiling-Point. }\end{array}$ & $\mathbf{K}_{1}=\frac{\mathrm{T}_{\mathbf{B P}}}{\sqrt[3]{\mathbf{V}}}$ \\
\hline \multicolumn{4}{|l|}{ Aromatic Ethers. } \\
\hline Phenyl propyl ether. & 46355 & 1720 & $83 \cdot 3$ \\
\hline Phenyl butyl ether ... & 4833 & 1953 & $83 \cdot 3$ \\
\hline Phenyl octyl ether. & $555 \cdot 8$ & $296 \cdot 1$ & $8: 3 \cdot 4$ \\
\hline o-'Tolyl etliyl ether ..... & $457 \cdot 8$ & $170 \cdot 9$ & $82 \cdot \tilde{0}$ \\
\hline o-Tolyl butyl ether .... & $495 \cdot 0$ & $218 \cdot 4$ & $82 \cdot 2$ \\
\hline m-Tolyl ethyl ether $\ldots$ & 4650 & 1720 & 836 \\
\hline 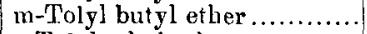 & $502 \cdot 2$ & 22115 & $83 \cdot 1$ \\
\hline p-Tolyl ethyl ether $\ldots \ldots \ldots \ldots \ldots$ & 4629 & 1721 & $83 \cdot 2$ \\
\hline p-Tolyl propyl ether $\ldots$ & $483 \cdot 4$ & 1960 & $83 \cdot 2$ \\
\hline \multicolumn{4}{|l|}{ Aliphatic Chlorides. } \\
\hline Ethyl chloride & $285 \cdot 2$ & $71 \cdot 2$ & $68 \cdot 8$ \\
\hline Propyl chloride & $319 \cdot 2$ & $91 \cdot 4$ & $70 \div 1$ \\
\hline Isopropyl chloride & $309 \cdot 5$ & 936 & $68 \cdot 2$ \\
\hline Isoamyi chloride ... & $37 \div 6$ & $134 \cdot 4$ & $7 \cdot 7 \cdot 7$ \\
\hline Amyl chloride ......... & $37+5$ & $136: 3$ & $72 \cdot 5$ \\
\hline Allyl chloride ......... & $318 \cdot 5$ & $84 \cdot 5$ & 726 \\
\hline \multicolumn{4}{|l|}{ Aliphatic Bromides. } \\
\hline Methyl bromide & 286 & $58 \cdot 2$ & $73 \cdot 8$ \\
\hline Ethyl bromide ..... & 3127 & $77 \cdot 7$ & 730 \\
\hline Propyl bromide ......... & $3+4$ & $97 \cdot 2$ & 748 \\
\hline Isopropyl bromide ..... & 333 & $97 \cdot 2$ & $71 \cdot 9$ \\
\hline \multicolumn{4}{|l|}{ Aliphatio Iodides. } \\
\hline Methyl iodide ..... & $315 \cdot 8$ & $84 \cdot 1$ & $78 \cdot 1$ \\
\hline Ethyl iodide ......... & $345 \cdot 3$ & $86 \cdot 1$ & $78 \cdot 2$ \\
\hline Propyl iodide ..... & 3755 & $106 \cdot 9$ & $79 \cdot 1$ \\
\hline n. Arngl iodide ..................... & 4247 & $150 \cdot 4$ & $79 \cdot 9$ \\
\hline 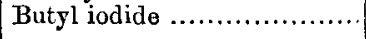 & 4029 & $128 \cdot 2$ & $79 \cdot 9$ \\
\hline \multicolumn{4}{|l|}{ Amines. } \\
\hline Dietliflamine & 329 & $109 \cdot 1$ & $68 \cdot 8$ \\
\hline Triethylamine ... & 362 & $153 \cdot 8$ & $67 \cdot 6$ \\
\hline Tripropylamine $\ldots . . . . .$. & $4: 9 \cdot 5$ & $222 \cdot 1$ & $70 \cdot 9$ \\
\hline Isobutylamine ............... & $340 \cdot 7$ & 1062 & $71 \cdot 9$ \\
\hline Chloroform & $334 \cdot 1$ & $84 \cdot 5$ & $76 \cdot 1$ \\
\hline Carbon tetrachloride .... & $349 \cdot 7$ & $103 \cdot 7$ & $74 \cdot 3$ \\
\hline Ethylene chloride $\ldots . . . \ldots \ldots \ldots \ldots$ & 356.5 & $85 \cdot 2$ & $81 \cdot 0$ \\
\hline Ethylidene chloride ............. & $331 \cdot 8$ & 887 & $74 \cdot 4$ \\
\hline Chlorobenzene ....................... & 4050 & $114 \cdot 3$ & $83 \cdot 5$ \\
\hline Bromobenzene .................... & 4290 & 1198 & $85 \cdot 0$ \\
\hline 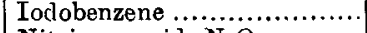 & $461 \cdot 4$ & $130 \cdot 6$ & $90 \cdot 9$ \\
\hline Nitric peroxide $\mathrm{N}_{2} \mathrm{O}_{4} \quad \ldots \ldots \ldots$ & $294 \cdot 6$ & $63 \cdot 9$ & 737 \\
\hline Sulphur dioxide $\ldots \ldots \ldots \ldots \ldots$ & 265 & $43 \cdot 9$ & $75 \cdot 1$ \\
\hline Carbon bisulphide.......... & 319 & $6 \cdot 1$ & $80 \cdot 6$ \\
\hline Tin tetrachloride ............... & $387 \cdot 1$ & $131 \cdot 2$ & $76 \cdot 3$ \\
\hline
\end{tabular}




\begin{tabular}{|c|c|c|c|}
\hline \multicolumn{4}{|c|}{ Liquids uhich shou Molecular Association. } \\
\hline Liquid. & $\begin{array}{l}\text { Temperature } \\
\text { of Boiling } \mathbf{T}_{\mathbf{B P}} \\
\text { (absolute). }\end{array}$ & $\begin{array}{c}\text { Molecular } \\
\text { Volume V at } \\
\text { Boiling-Point. }\end{array}$ & $K_{1}=\frac{T_{m}}{\sqrt[3]{ } V}$. \\
\hline Water & 373 & $18 \cdot 78$ & 1403 \\
\hline Methyl alcobol & $337 \cdot 9$ & 42.6 & $97 \cdot 1$ \\
\hline Ethyl alcohol & $351 \cdot 3$ & $62 \cdot 2$ & 887 \\
\hline n. Propyl alcohol & $370 \cdot 4$ & $81 \% 2$ & $85 \cdot 1$ \\
\hline n. Hexyl alcohol & $429 \cdot 6$ & $146 \cdot 3$ & 81.5 \\
\hline Formic acid ........ & 373 & $41 \cdot 1$ & $108 \cdot 1$ \\
\hline Acetic acid & 391.5 & 63.6 & 98.0 \\
\hline Propionic acid .... & 413.8 & $85 \cdot 5$ & $93 \cdot 9$ \\
\hline Butyric acid ................ & 435 & 108 & $91 \cdot 3$ \\
\hline Methyl formate. & $30+7$ & $60 \cdot 10$ & $76 \cdot 65$ \\
\hline Methyl oxalate .... & 435.6 & $116 \cdot 8$ & $89 \cdot 1$ \\
\hline Ethyl oxalate .... & $459 \cdot 0$ & $166^{2} 2$ & 835 \\
\hline Propyl oxalate .......... & $486 \cdot 5$ & $215 \cdot 4$ & 81.2 \\
\hline Diniethyl succinate....... & $468 \cdot 2$ & $159 \cdot 7$ & $86 \cdot 3$ \\
\hline Methyl ethyl succinate & $481 \cdot 2$ & $184 \cdot \overline{6}$ & $84 \cdot 6$ \\
\hline Dietliyl succinate................ & $489 \cdot 2$ & $209 \cdot 6$ & $82 \cdot 5$ \\
\hline Acetonitrile .................... & 347 & $54: 3$ & $91 \cdot 7$ \\
\hline Propionitrile ..... & 370 & $78 \cdot 3$ & $80 \cdot 1$ \\
\hline Valeronitrile ..................... & 412 & $119 \cdot 7$ & $81 \cdot 6$ \\
\hline Phenol ............ & 467 & $103 \cdot 6$ & $99 \cdot 4$ \\
\hline
\end{tabular}

It will be observed from the Table that the relation gives an approximately constant value of $\mathrm{K}$ for all the homologous series, but the value varies considerably from one homologous series to another. In general the higher boiling liquids seem to give rather high values of $K$. The approximate values of the constant for the different homologous series are given below.

The aliphatic hydrocarbons and ethers give $\mathrm{K}=68$. The aliphatic chlorides and amines give $K=70$. The aliphatic esters and bromides give $\mathrm{K}=74$. The aliphatic iodides and aromatic hydrocarbons give $\mathrm{K}=79$. The aromatic ethers give $\mathrm{K}=83$.

The validity of the relation is also considerably affected hy molecular association, as the latter portion of the above Tible indicates. For associated liquids the equation should obviously be written

$$
\mathrm{T}=\mathrm{K} \sqrt[3]{\overline{\mathrm{V}}} n,
$$

where $n$ is the association factor.

Were it not for the uncertainty of the value of $K$ for $2 \mathrm{~N} 2$ 
any particular liquid, the above equation would furnish a method of determining $n$ the associntion factor.

There is one way of distinguishing between the effects of association and constitution. If the members of an homologous series give a gradually diminishing value of $K$ as the series is ascended, then the members of that particular series show molecular association. If the value of $\mathrm{K}$ remains approximately constant then no molecular association occurs. For this reason the esters of the aliphatic dibasic acids, like oxalic and succinic, have been classed along with the alcohols and acids as associated liquids.

Mention must be made here of other relations between the molecular volume and the boiling-point. It has long been noticed in a general way that there is a certain parallelism between the molecular volume and the boiling-point, but no exact relation has yet been discovered. Masson (Phil. Mag. vol. xxx. p. 412, 1890) discovered empirically the relation $\mathrm{V}$ $\mathrm{V}=$ constant, where $\mathrm{V}$ and $\mathrm{T}$ are the molecular volume and temperature of boiling respectively, which he found to hold closely for the alkyl halides, but apparently only for these few classes of substances.

On the other hand, Young (Phil. Mag.vol. xxx.p. 423, 1890) showed that Masson's relation should only hold for substances which have the same critical pressures, and deduced the relation (from van der Waals' generalizations)

$$
\mathrm{V}=\text { const. } \times \frac{\mathrm{T}_{\mathrm{c}}}{\mathrm{P}_{c}}
$$

where $V$ is the molecular volume at the boiling-point, $T_{c}$ is the critical temperature, and $\mathrm{P}_{o}$ the critical pressure. Obviously for those liquids where $\mathrm{P}_{e}$ is constant, Masson's relation will hold.

\section{Summary.}

An empirical relation between the latent heat of a liquid and the molecular volume at the boiling-point is shown to hold for most classes of liquids, with the exception of the aliphatic hydrocarbons and ethers and liquids which show molecular association. The relation may be written

$$
\mathrm{LM}=\mathrm{K} \sqrt[3]{\mathrm{V}},
$$

where $L_{\text {is }}$ the latent heat at the boiling-point, $M$ the molecular weight, $V$ the molecular volume at the boiling-point, and $K$ is a constant equal to 1583 . 'The effect of molecular 
association on the validity of the relation is examined and it is shown that with associated liquids the calculated value of the latent heat may be either greater or smaller than the actual observed value.

The relation combined with Trouton's equation gives the simple relation

$$
\mathrm{T}=\mathrm{K} \sqrt[3]{\mathrm{V}},
$$

where $\mathrm{T}$ is the boiling-point, $\mathrm{V}$ the molecular volume at the boiling-point, and $\mathrm{K}$ is a constant. This relation gives a fiarly constant value of $K$ for the members of an homologous series, but its value varies rather considerably from one homologous series to another. The relation is also greatly affected by molecular association, the value of $\mathrm{K}$ always being much greater for associated liquids than the average.

The Chemical Department,

The University, Manchester.

LIII. The Energy Relations of Certain Detectors used in Wireless Telegraphy. By W.H. Eccles, D.Sco, A.R.C.S.*

[Plate X.]

THE results of an experimental examination into the 1 physical properties of four very different types of detector used in radio-telegraphy are set forth briefly in the following pages. The conditions of the experiments have been made generally identical with those arising in the ordinary employment of the detectors, and, in particular, the quantities of energy given to the instruments, in the form of electrical oscillations, have been of the same order in these experiments as in actual practice. The detectors investigated are the electrolytic, the carborundum rectifier, the zincite detector, and a thermoelectric detector. All these have before this been subjected to close scrutiny by various observers, who, however, used methods different from that of this paper; a summary of their work will be given alongside the results of the present experiments. These results, it will be seen, are expressed in the form of curves rather than as tables of figures; each curve may be regarded as typical of the detector concerned, and has been selected from a number of curves drawn from measurements accumulated during last year.

The method and apparatus used are the same as were described in a paper "On Coherers" read before the Physical

* Communicated by the Physical Society: read July 8, 1910. 